\title{
Effect of Foaming Agent on Quality and Yield of Foam Mat Dried Papaya Powder
}

\author{
Shivani $^{1}$, Anil K Verma ${ }^{1}{ }^{*}$, PC Sharma ${ }^{1}$, Anil Gupta ${ }^{2}$ and Manisha Kaushal ${ }^{2}$ \\ ${ }^{1}$ Department of Food Science and Technology, College of Horticulture \& Forestry-Neri, \\ Hamirpur, India \\ ${ }^{2}$ Department of Food Science and Technology, Dr Y S Parmar University of Horticulture \& \\ Forestry Nauni, Solan, HP, India \\ *Corresponding author
}

\section{Keywords \\ Papaya pulp, Glycerol monostearate, CMC, whipping, Foam expansion, Foam thickness, Drying}

\section{Article Info}

Accepted:

20 November 2019

Available Online:

10 December 2019

\section{A B S T R A C T}

The study was carried out for utilization of papaya fruit cv. Madhu for preparation of foam mat dried fruit powder. The conversion of papaya pulp into foam was optimized by whipping the pulp after addition of glycerol-mono-stearate (GMS) and drying the resultant foam in dehydrator $\left(60 \pm 5^{\circ} \mathrm{C}\right)$ to constant moisture content. Drying of papaya foam by using 3\% GMS results in 11.93 per cent yield and was found the most appropriate with respect to desired foaming properties (foam density, foam expansion and foam stability), physico-chemical as well as sensory characteristics. With the increase in the foaming agent concentration, the foam density decrease significantly however; the percentage of foam expansion was increased. In comparison to foam density, the papaya pulp exhibited higher foam expansion of 21.72 per cent with $3 \%$ GMS in sweetened pulp. The dried powder by using $3 \%$ GMS contained $84.07-89.83^{\circ} \mathrm{B}$ TSS, $7.00-8.28 \%$ moisture content, $2.40-4.50 \%$ ash content, $52.47-62.63 \%$ reducing sugars, $81.39-87.73 \%$ total sugars, 928.76-1242.98 $\mu \mathrm{g} / 100 \mathrm{~g}$ total carotenoids respectively in natural and sweetened papaya pulp. There was no significant change in other biochemical constituents such as $\mathrm{pH}$ and acidity. Thus, the papaya fruit can be utilized for preparation of self-stable powder using foam mat drying technique for further preparation of ready to drink beverages.

\section{Introduction}

Papaya (Carica papaya L.) is an important tropical and sub-tropical fruit crop in the world that is widely preferred for its nutritional values (Sidhu, 2006). Papaya fruits are rich in nutrients especially $\beta$-carotene, Vitamin A, Vitamin $\mathrm{C}$, minerals like potassium and magnesium and are good source of energy (Gopalan et al., 1989;
Widyastuti et al., 2003). Besides, the papaya fruit juice also contains alkaloids, glycosides, flavonoids, carbohydrates, saponins, terpenoids, steroids and tannins. The extract of various parts of papaya has multifarious uses such as anti-hypertensive, anti-inflammatory, anti-tumour, anti-fungal, anti-microbial, antisickling and anti-ulcer activity (Vij and Prashar, 2015). Papaya fruit is mostly consumed fresh but can also be utilized for 
making processed products like puree, jam, jelly, pickle, nectar, papaya cake, barfi, halwa, baby food, tuty-fruity, candied fruit, mixed beverages, canned slices/chunks, concentrate etc. to extend its shelf-life and period of availability in the market (Rajarathnam, 2010).

In India, the annual production of papaya is 6.216 million Metric tonnes from an area of 0.143 million hectare contributing $2.19 \%$ of total area under fruit crops (NHB, 2018). In Himachal Pradesh, papaya cultivation covered an area of 0.23 thousand hectare with an annual production of 1.11 thousands Metric tonnes during the year 2018 (NHB, 2018); and this crop is being extensively grown in mid and low hills of the state. Owing to highly perishable nature and nearly $88 \%$ of moisture, papaya fruits cannot be stored for longer periods under ambient conditions. In India, total estimated postharvest losses of $25.49 \%$ are recorded (Gajanana et al., 2010).

Among various methods of preservation, foam mat drying is an alternate technique to mitigate the post-harvest losses and enhance keeping quality. It is one of the simple techniques of drying where liquid concentrate is transformed into suitable foam with the help of foaming agents and the resultant foam is dried at low temperature (Meenaet al.2014). Foam mat drying is an appropriate method for heat sensitive and thick materials as compared to drum and spray drying due to better reconstitution property of final dried material. According to Kudra and Ratti (2006) rehydration and retention of volatiles are important properties which are maintained by foam mat drying.Foam mat drying have been used in many fruits such as guava, mango, apple, banana (Rajkumar et al., 2007a, b), pineapple and tomato (Jayaraman, 1993; Hassan and Ahmed 1998). Sankat and Castaigne (2004); Thuwapanichayanan et al., (2008) have reported higher drying rate at the end of drying period in banana, Kadam et al., (2010) in mango and Kadam and Balasubramanian (2011) and Kadam et al., (2011) in tomato juice.

Keeping in view the availability of papaya fruit in low-hills of Himachal Pradesh, papaya pulp was converted into powder by adopting a simple foam mat drying technique for further utilization of powder in preparation of instant value added products.

\section{Materials and Methods}

\section{Selection of fruits and foaming agent}

Papaya fruits cultivar 'Madhu' on the basis of their commercial importance and availability in the low hills zone of Himachal Pradesh (Hamirpur) were selected for preparation of Instant Papaya Fruit Powder using Foam-mat drying technique. The pulp of fruits was prepared by adding $10 \%$ water $(100 \mathrm{ml} / \mathrm{kg}$ fruits), followed by heating for 10 minutes to soften and finally pulp was prepared with the help of blender (Robot 5.0 SS INALSA). The pulp so obtained was preserved with potassium meta-bisulphite $(2 \mathrm{~g} / \mathrm{kg}$ of pulp) and packed in plastic cans for its later utilization in Instant papaya powder and for other analytical purposes. The papaya natural $\left(8^{\circ} \mathrm{B}\right)$ as well as sweetened pulp $\left(20^{\circ} \mathrm{B}\right.$ TSS after addition of sugar syrup) was evaluated.

Thepapaya pulp was converted into thick stable foam by whipping the pulp after adding carboxy methyl cellulose (CMC) or glycerol monostearate (GMS) in 1-3\% concentrations alongwith control treatments. The prepared foam was spread into the stainless steel trays in thin layer and dried to a constant weight in mechanical dehydrator (cabinet drier) at $60 \pm 5^{\circ} \mathrm{C}$. The dried foam was scrapped/removed from the trays and ground to a fine powder. The complete process for preparation of foam mat dried powder is given 
in Figure-1.

\section{Physico-chemical characteristics}

The physical characteristics of fresh papaya fruits were determined by using Vernier Calliper, weight in grams was determined gravimetrically and expressed as mean weight (g).The peel/pulp ratio was calculated by using the following formula:

Peel :Pulp ratio $=$

Weight of the fruits - Weight of the fruits after peeling

Weight of the fruits - Weight of the fruits peel

The total soluble solids of papaya pulp and prepared powder were determined with the help of hand refractrometer and expressed as degree Brix $\left({ }^{\circ} \mathrm{B}\right)$ at $20^{\circ} \mathrm{C}$ (Ranganna, 2014). The moisture content was estimated by drying the weighed sample to a constant weight in hot air oven at $70 \pm 5{ }^{0} \mathrm{C}$ followed by cooling at ambient temperature in desiccators prior to weighting (Ranganna, 2014). The titratable acidity, carotenoids, ash contents, total and reducing sugars of pulp and fruit powder were determined by following method as detailed by Ranganna (2014). The drying rate/ratio and equilibrium relative humidity of the samples were estimated by plotting the data against relative humidity to determine ERH of given samples (Ranganna, 2014). ThepHof the papaya pulp and prepared powder (after dilution) was determined with the help of automatic $\mathrm{pH}$ meter (Deluxe $\mathrm{pH}$ meter model 101). Before estimation, the $\mathrm{pH}$ meter was calibrated with buffer solution of $\mathrm{pH} 4.0$ and pH 7.0 (AOAC, 1995).

\section{Foam density}

The density of the foamed papaya pulp was calculated as ratio of mass of foam to the volume of foam and expressed as $\mathrm{g} / \mathrm{cm}^{3}$ (Falade et al., 2003). The density of papaya pulp was determined by weighing $100 \mathrm{ml}$ of the pulp in a $100 \mathrm{ml}$ measuring cylinder whereas for the foamed papaya pulp, $200 \mathrm{ml}$ of foam was transferred into a $250 \mathrm{ml}$ measuring cylinder and weighed. The foam density was calculated using the following formula:

$$
\begin{aligned}
& \text { Foam Density }(\mathrm{FD})=\text { Mass of the foam }(\mathrm{g}) \\
& \text { Volume of the foam }\left(\mathrm{cm}^{3}\right)
\end{aligned}
$$

\section{Foam expansion}

It is the percentage increase of the volume of the pulp after foaming with required amount of the foaming agent and whipping time. The foam quality of foamed papaya pulp in terms of foam expansion was calculated according to the following equation (Akiokato et al., 1983).

$$
\begin{gathered}
V_{1}-V_{0} \\
\text { Foam Expansion }(\mathrm{FE})=\frac{\mathrm{-a}}{\mathrm{V}_{0}}
\end{gathered}
$$

Where,

$\mathrm{V}_{0}=$ initial volume of the papaya pulp before foaming $\left(\mathrm{cm}^{3}\right)$,

$\mathrm{V}_{1}=$ final volume of the papaya pulp after foaming $\left(\mathrm{cm}^{3}\right)$.

\section{Foam stability}

$50 \mathrm{ml}$ of foamed pulp was placed in a $50 \mathrm{ml}$ glass tube and kept undisturbed in normal atmosphere for 2 hours (Marinova et al., 2009). Then, the decrease of the foam volume was noted in every 30 minute time interval and was noted to be used as an index for the determination of the stability for every 30 minutes by using following relationship:

$$
\text { Foam Stability }(\mathrm{FS})=\frac{\mathrm{V}_{0}}{\mathrm{~V}_{1}} \times 100
$$


Where, FS is expressed in percentage (\%), $\mathrm{V}_{0}$ is the final volume of the papaya pulp after 2 hours of foaming and $V_{1}$ is the initial volume of the papaya pulp after foaming.

\section{Sensory and statistical analysis}

Ninepoints hedonic scale method as suggested by Amerine et al., (1965) was followed for conducting the sensory evaluation of foam mat dried papaya powder. Total plate count (TPC) was estimated by aseptically inoculating 0.1 gram of serially diluted sample (powder) in total plate count/standard plate count agar medium prepared according to Ranganna (2014). The datapertaining to sensory evaluation of papaya powder were analyzed according to Randomized Block Design (RBD) as described by Mahony (1985), while the data on physico-chemical characteristics of fruit, fruit pulp and instant powder were analyzed statistically by following Completely Randomized Design (CRD) of Cochran and Cox (1967).

\section{Results and Discussion}

Physico-chemical characteristics of fresh papaya fruits

The physico-chemical characteristics of papaya fruit cultivar 'Madhu' assessed during the present study are presented in Table 1 . The mean length, diameter and weight of papaya fruit cv. 'Madhu' was found as $15.00 \pm 0.10$ $\mathrm{cm}, 11.36 \pm 0.18 \mathrm{~cm}$ and $1100.00 \pm 57.008 \mathrm{~g}$, respectively with a peel:pulp ratio of 1:6. The pulp yield in papaya was recorded as $82.60 \pm 0.920$ per cent.The average total soluble solids (TSS) in fresh papaya fruit cv. 'Madhu' was $8.00 \pm 0.07^{\circ} \mathrm{B}$, acidity 0.033 per cent with $\mathrm{pH}$ 5.73. The results were found to be slightly lower than the observations of Parker et al., (2010), Santos and Realpe (2013) and Attri et al., (2014). Bari et al., (2006) reported very low (0.005 per cent) titratable acidity in papaya fruit. The level of $\mathrm{pH}$ in papaya fruits was in-conformity with the findings of Sana et al., (2009), Reni et al., (2000) and Chauhan and Chatterjee, (2005). The moisture content of $87.00 \pm 0.070$ per cent was recorded which was in conformation with those of Chukwuka et al., (2013), Sana et al., (2009), Attri et al., (2014), Ahuja et al., (2008) and Othman (2009).

The content of reducing sugars and total sugars in fresh papaya fruits cv. 'Madhu' were found to be 5.53 and 7.39 per cent respectively, which were similar to the values recorded by Zamen et al., (2006) and Reni et al., (2000). The total carotenoids were 799.68 $\mu \mathrm{g} / 100 \mathrm{~g}$, however slightly lower values (666 $\mu \mathrm{g} / 100 \mathrm{~g}$ ) have been recorded by Gopalan et al., (2004) in papaya fruit. Devaki et al., (2015) reported that total carotenoids content increased from mature stage to fully ripe stage and vary according to agronomic practices and planting time.

\section{Effect of different foaming agents on foaming characteristics}

The results presented in Table 2 represent the foaming properties of both natural (unsweetened) as well as sweetened papaya pulps while were converted into a foam by whipping for 5 minute after addition of CMC (1-3\%) and GMS (1-3\%) as foaming agents in different concentrations.

\section{Foam density $\left(\mathrm{g} / \mathrm{cm}^{3}\right)$}

It is evident from Table 2 that natural pulp exhibited significantly higher $\left(0.91 \mathrm{~g} / \mathrm{cm}^{3}\right)$ foam density as compared to foam density of sweetened pulp $\left(0.81 \mathrm{~g} / \mathrm{cm}^{3}\right)$. Among different foaming agent, foam density ranged between 0.76 to $0.99 \mathrm{~g} / \mathrm{cm}^{3}$ and foam prepared by using CMC (1-3\%) exhibited higher density (0.99$\left.0.83 \mathrm{~g} / \mathrm{cm}^{3}\right)$ as compared to GMS (0.76-0.87 $\left.\mathrm{g} / \mathrm{cm}^{3}\right)$. Reduction in foam density with 
increasing foaming agents has also been reported by Rajkumar and Kailappan (2006) in Totapuri cultivar of mango and in bael fruit pulp, foam density ranged between 0.58-0.917 $\mathrm{g} / \mathrm{cm}^{3}$ by Bag et al., (2011). According to Affandi et al., (2017) the reduction in foam density with increasing concentration of foaming agents was probably due to the reduction in the interfacial tension and surface tension of the pulp which form an interfacial film as reported by.

\section{Foam expansion}

Data given in Table 2 reveal that the foam expansion was significantly higher (15.27 per cent) in sweetened pulp than that of unsweetened pulp (8.13 per cent). Among the different foaming agents, use of GMS exhibited higher (19.40 per cent) foam expansion as against 7.33-13.26 per cent expansion in the foam obtained by using CMC. Further, increase in concentration of foaming agent caused more expansion of foam in both the foaming agents, which was probably due to incorporation of more air in to the pulp during the foaming process. The maximum foam expansion was 21.72 per cent in sweetened pulp treated with 3\% GMS. Similar results were reported by Affandi et al., (2017) and Rajkumar and Kailappan (2006). Foam expansion is the inverse of foam density.

\section{Foam stability}

A perusal of data in Table 2 also reveals that the foam stability was significantly higher (99.59 per cent) in sweetened pulp as compared to natural pulp (97.69 per cent). Among the different concentration of foaming agents with the increase in the concentration of foaming agents (1-3\%) the values of foam stability increased to $97.26-98.25$ per cent by using CMC and 99.13-99.97 per cent by using GMS. Similar findings have been reported by Affandi et al., (2017), Rajkumar and
Kailappan (2006). According to Kandasamy et al., (2012b), the foam stability decrease with decreasing the pulp concentration and increase in drainage volume.

\section{Drying time}

The papaya pulp after turning in to foam by using different foaming agents was dried in a cabinet drier at $60 \pm 5^{\circ} \mathrm{C}$.Data given in Table 3 reveal that the average drying time for pulp with different concentration varied between 7.40 to 9.25 hours. The effect of foaming agents on foam mat drying of pulp is also presented in Figure 2. As expected, the sweetened pulp dried as such without using foaming agents, took the longest (9.25 hours) time for drying while foaming of pulp brought about significant reduction in drying time of the pulp. Mean drying time for un-foamed control pulp was 8.77 hours which reduced to 7.95 to 8.67 hours in foamed pulp by using CMC (1-3\%) and only 7.87 to 8.30 hours in papaya pulp foamed by using GMS (1-3\%) foaming agent. Sharma et al., (2002) reported higher (20.30 hours) time for non-foamed hill lemon juice powder as compared to foamed lemon juice (19.40-17.15 hours). Gupta and Alam (2014) also stated that drying time was reduced (490-180 minutes) with increasing the concentration of foaming agents.

\section{Pulp Yield (\%)}

A perusal of data in Table 3 reveals that the average yield varied from 10.10 per cent to 11.93 per cent in natural and sweetened pulp powder among different concentrations of foaming agents. As expected, the natural pulp dried as such without using foaming agents gave lower yield (10.10 per cent) while foaming of sweetened pulp brought a significant increase in yield of the dried powder. Mean yield for un-foamed control pulp was as 10.40 per cent which increased to 10.60 to 10.90 per cent in foamed pulp by using $\mathrm{CMC}(1-3 \%)$ and 11.25 to 11.78 per 
cent by using GMS (1-3\%) foaming agent. Higher yield of powder from sweetened pulp was attributed to the presence of higher solids in sweetened pulp as compared to natural pulp. Similar increasing trend with increase in concentration of foaming agents have been reported by Sharma et al., (2002) in foam mat dried hill lemon juice powder (8.03-11.18 per cent).

\section{Quality characteristics of foam mat dried powder}

The data pertaining to quality evaluation of foam mat dried papaya powder presented in Tables 4-5 are discussed as under:

\section{Total soluble solids (TSS)}

Data in Table 4 indicate that the papaya powder prepared from sweetened pulp exhibited significantly higher $\left(89.4^{\circ} \mathrm{B}\right) \mathrm{TSS}$ as compared to powder from unsweetened natural pulp $\left(82.4^{\circ} \mathrm{B}\right)$. Among different foaming agents, the powder from un-foamed pulp had $83.5^{\circ} \mathrm{B}$ TSS which increased to 84.6 to $86.5^{\circ} \mathrm{B}$ in powder prepared by using $\mathrm{CMC}$ $(1-3 \%)$ and 85.6 to $86.9^{\circ} \mathrm{B}$ in GMS (1-3\%) treated foamed papaya pulp powder. The powder prepared by using 3\% GMS resulted in a TSS of $86.9^{\circ} \mathrm{B}$ which was similar to the findings of Sharma et al., (2002). Similar trend of increase in total soluble solids with increase in foaming agent concentration (020\%) has been reported by Shaari et al., (2017).

\section{Moisture and ash content}

Data presented in Table 4 indicate that among different foaming agents, the powder from non-foamed pulp had 9.6 per cent moisture which reduced to 9.1 to 7.9 per cent for CMC (1-3\%) and 8.8 to 7.6 per cent for GMS (1$3 \%$ ) treated foamed papaya pulp powder. Among different concentration of foaming agents, the increase in concentration of the foaming agents, the moisture content of the powder exhibited decrease. The powder prepared by using 3\% GMS resulted in moisture content of 7.64 per cent. Similar to these findings, Sharma et al., (2004) in hill lemon juice powder, Shaari et al., (2017) in pineapple powders, Auisakchaiyoung and Rojanakorn (2015) in dried Gac fruit aril and Ojo et al., (2015) in dried pineapple and cashew apple juice powder also observed decrease in moisture content.

The ash content ranged between 4.9 to 3.9 per cent in powder prepared by using CMC (1$3 \%$ ) and 4.3 to 3.5 per cent in GMS (1-3\%) treated foamed papaya pulp powder. The powder prepared by using 1\% CMC resultant in ash content of 4.9 per cent. Earlier, Patil et al., (2014) has reported increase in ash content (1.5-3.3 per cent) with subsequent increase in malto-dextrin foaming agent concentration (712 per cent) in guava powder.

\section{Reducing sugars}

The papaya powder prepared from sweetened pulp showed significantly higher (62.3 per cent) reducing sugars as compared to powder from unsweetened natural pulp (51.2 per cent). Among different foaming agents, the reducing sugars of powder from un-foamed pulp had 55.0 per cent reducing sugars (Table 4). The reducing sugars in foam mat dried powder increased from 56.0 to 57.2 per cent with increased concentration of CMC (1-3\%) and 56.1 to 57.6 per cent with 1-3\% GMS.Earlier Akhtar et al., (2010) has also observed increase in reducing sugars from juice to mango juice powder Reducing sugars increased with increasing the concentration of foaming agent because acidic hydrolysis of sugars resulting in breakdown of disaccharides into mono-saccharides and conversion of nonreducing sugars into reducing sugars (Kadam et al., 2010). 
Table.1 Physico-chemical characteristics of Fresh Papaya fruit (cv. Madhu)

\begin{tabular}{|c|c|c|}
\hline $\begin{array}{c}\text { S. } \\
\text { No. }\end{array}$ & Parameters & Mean \pm SE* \\
\hline \multicolumn{3}{|c|}{ Physical characteristics } \\
\hline 1 & Length $(\mathrm{cm})$ & $15.00 \pm 0.10$ \\
\hline 2 & Diameter $(\mathrm{cm})$ & $11.36 \pm 0.18$ \\
\hline 3 & Weight (g) & $1100.00 \pm 57$ \\
\hline 4 & Peel/Pulp ratio & 1: 6 \\
\hline 5 & Pulp yield (\%) & $82.60 \pm 0.92$ \\
\hline \multicolumn{3}{|c|}{ Chemical characteristics } \\
\hline 6 & $\operatorname{TSS}\left({ }^{0} \mathrm{~B}\right)$ & $8.00 \pm 0.07$ \\
\hline 7 & Titratable acidity (\%) & $0.033 \pm 0.01$ \\
\hline 8 & $\mathrm{pH}$ & $5.73 \pm 0.05$ \\
\hline 9 & Reducing sugars (\%) & $5.53 \pm 0.06$ \\
\hline 10 & Total sugars (\%) & $7.39 \pm 0.04$ \\
\hline 11 & Total carotenoids $(\mu \mathrm{g} / 100 \mathrm{ml})$ & $799.68 \pm 3.43$ \\
\hline 12 & Moisture content (\%) & $87.00 \pm 0.70$ \\
\hline
\end{tabular}

* $\mathrm{SE}=$ Standard Error, $\mathrm{n}=5$

Table.2 Effect of foaming agents on foaming characteristics of papaya pulp

\begin{tabular}{|c|c|c|c|c|c|c|c|c|c|c|}
\hline \multirow{3}{*}{$\begin{array}{c}\text { Foaming } \\
\text { agents }\end{array}$} & \multirow{3}{*}{$\begin{array}{c}\text { Concentration } \\
(\%)\end{array}$} & \multicolumn{9}{|c|}{ Foaming characteristics } \\
\hline & & \multicolumn{3}{|c|}{$\begin{array}{c}\text { Foam Density } \\
\left(\mathrm{g} / \mathrm{cm}^{3}\right)\end{array}$} & \multicolumn{3}{|c|}{$\begin{array}{c}\text { Foam Expansion } \\
(\%)\end{array}$} & \multicolumn{3}{|c|}{ Foam Stability (\%) } \\
\hline & & NP & SP & Mean & NP & SP & Mean & NP & SP & Mean \\
\hline \multirow{3}{*}{ CMC } & 1.0 & 1.01 & 0.97 & 0.99 & 3.00 & 7.33 & 5.17 & 95.12 & 99.40 & 97.26 \\
\hline & 2.0 & 0.94 & 0.82 & 0.88 & 4.38 & 9.78 & 7.08 & 96.66 & 99.43 & 98.05 \\
\hline & 3.0 & 0.90 & 0.75 & 0.83 & 5.23 & 13.26 & 9.24 & 97.06 & 99.44 & 98.25 \\
\hline \multirow{4}{*}{ GMS } & 1.0 & 0.91 & 0.84 & 0.87 & 7.21 & 19.39 & 13.29 & 98.67 & 99.59 & 99.13 \\
\hline & 2.0 & 0.85 & 0.77 & 0.81 & 11.90 & 20.14 & 16.02 & 98.74 & 99.66 & 99.20 \\
\hline & 3.0 & 0.83 & 0.69 & 0.76 & 17.08 & 21.72 & 19.40 & 99.93 & 100.00 & 99.97 \\
\hline & Mean & 0.91 & 0.81 & & 8.13 & 15.27 & & 97.69 & 99.59 & \\
\hline \multicolumn{11}{|l|}{$\mathrm{CD}_{0.05}$} \\
\hline \multirow{2}{*}{\multicolumn{2}{|c|}{$\begin{array}{l}\text { Pulp }(P) \\
\text { Foaming agent }(F)\end{array}$}} & \multicolumn{3}{|c|}{0.055} & \multicolumn{3}{|c|}{1.002} & \multicolumn{3}{|c|}{0.899} \\
\hline & & \multicolumn{3}{|c|}{0.095} & \multirow{2}{*}{\multicolumn{3}{|c|}{1.736}} & \multicolumn{3}{|c|}{1.480} \\
\hline \multicolumn{2}{|l|}{$P \times F$} & \multicolumn{3}{|c|}{ NS } & \multicolumn{2}{|r|}{2.455} & & \multicolumn{3}{|c|}{ NS } \\
\hline
\end{tabular}

Where, $\mathrm{CMC}=$ Carboxy methyl cellulose; $\mathrm{GMS}=$ Glycerol mono stearate; $\mathrm{NP}=\mathrm{Natural}$ pulp; $\mathrm{SP}=\mathrm{Sweetened} \mathrm{pulp}$ 
Table.3 Effect of foaming agents on drying time and yield of foamed papaya pulp

\begin{tabular}{|c|c|c|c|c|c|c|c|}
\hline \multirow{2}{*}{$\begin{array}{c}\text { Foaming } \\
\text { agents }\end{array}$} & \multirow{2}{*}{$\begin{array}{c}\text { Concentration } \\
(\%)\end{array}$} & \multicolumn{3}{|c|}{ Drying Time (hours) } & \multicolumn{3}{|c|}{ Pulp Yield (\%) } \\
\hline & & NP & SP & Mean & NP & SP & Mean \\
\hline \multirow{4}{*}{ CMC } & Control & 8.30 & 9.25 & 8.77 & 10.10 & 10.70 & 10.40 \\
\hline & 1.0 & 8.25 & 9.10 & 8.67 & 10.30 & 10.90 & 10.60 \\
\hline & 2.0 & 8.05 & 9.00 & 8.52 & 10.36 & 10.99 & 10.67 \\
\hline & 3.0 & 7.45 & 8.45 & 7.95 & 10.80 & 11.00 & 10.90 \\
\hline \multirow{3}{*}{ GMS } & 1.0 & 8.00 & 8.54 & 8.27 & 11.00 & 11.50 & 11.25 \\
\hline & 2.0 & 7.91 & 8.40 & 8.15 & 11.20 & 11.70 & 11.45 \\
\hline & 3.0 & 7.40 & 8.35 & 7.87 & 11.63 & 11.93 & 11.78 \\
\hline \multicolumn{2}{|c|}{ Mean } & 7.91 & 8.73 & & 10.88 & 11.34 & \\
\hline $\begin{array}{l}\mathrm{CD}_{0.05} \\
\text { Pulp (P) } \\
\text { Foaming } \\
\mathbf{P} \times \mathbf{F}\end{array}$ & gent $(F)$ & $\begin{array}{l}0.096 \\
0.167 \\
0.236\end{array}$ & & & $\begin{array}{l}0.049 \\
0.086 \\
0.085\end{array}$ & & \\
\hline
\end{tabular}

Where, $\mathrm{CMC}=$ Carboxy methyl cellulose GMS $=$ Glycerol mono stearate; $\mathrm{NP}=$ Natural pulp; $\mathrm{SP}=$ Sweetened pulp

Table.4 Effect of foaming agent on chemical characteristics of foam mat dried papaya powder

\begin{tabular}{|c|c|c|c|c|c|c|c|c|c|c|c|c|c|}
\hline \multirow[t]{2}{*}{$\begin{array}{l}\text { Foaming } \\
\text { agents }\end{array}$} & \multirow[t]{2}{*}{$\begin{array}{l}\text { Conc. } \\
(\%)\end{array}$} & \multicolumn{3}{|c|}{ TSS $*\left({ }^{\circ} \mathbf{B}\right)$} & \multicolumn{3}{|c|}{ Moisture content (\%) } & \multicolumn{3}{|c|}{ Ash content (\%) } & \multicolumn{3}{|c|}{$\begin{array}{l}\text { Reducing sugars } \\
(\%)\end{array}$} \\
\hline & & $\mathbf{N P}$ & SP & Mean & NP & SP & Mean & NP & SP & Mean & NP & SP & Mean \\
\hline \multirow{4}{*}{ CMC } & Control & 79.3 & 87.6 & 83.5 & 8.5 & 10.7 & 9.6 & 4.7 & 3.8 & 4.3 & 49.7 & 60.3 & 55.0 \\
\hline & 1.0 & 80.3 & 89.0 & 84.6 & 8.1 & 10.0 & 9.1 & 5.6 & 4.3 & 4.9 & 50.0 & 62.0 & 56.0 \\
\hline & 2.0 & 82.0 & 89.4 & 85.7 & 7.7 & 9.3 & 8.5 & 5.2 & 4.2 & 4.7 & 50.9 & 62.3 & 56.6 \\
\hline & 3.0 & 83.3 & 89.8 & 86.5 & 7.4 & 8.5 & 7.9 & 4.3 & 3.5 & 3.9 & 51.9 & 62.6 & 57.3 \\
\hline \multirow{4}{*}{ GMS } & 1.0 & 81.9 & 89.2 & 85.6 & 8.0 & 9.7 & 8.8 & 5.6 & 3.0 & 4.3 & 50.5 & 61.7 & 56.1 \\
\hline & 2.0 & 83.1 & 89.4 & 86.3 & 7.4 & 8.4 & 7.9 & 4.7 & 2.7 & 3.7 & 51.6 & 62.4 & 57.0 \\
\hline & 3.0 & 84.1 & 89.8 & 86.9 & 7.0 & 8.3 & 7.6 & 4.5 & 2.4 & 3.5 & 52.5 & 62.6 & 57.6 \\
\hline & Mean & 82.4 & 89.4 & & 7.6 & 9.0 & & 4.9 & 3.4 & & 51.2 & 62.3 & \\
\hline \multicolumn{2}{|c|}{$\mathrm{CD}_{0.05}$} & \multirow{2}{*}{\multicolumn{3}{|c|}{0.729}} & \multirow{3}{*}{\multicolumn{3}{|c|}{$\begin{array}{l}0.298 \\
0.516\end{array}$}} & \multirow{2}{*}{\multicolumn{3}{|c|}{0.265}} & \multirow{2}{*}{\multicolumn{3}{|c|}{0.470}} \\
\hline \multirow{2}{*}{\multicolumn{2}{|c|}{$\begin{array}{l}\text { Pulp (P) } \\
\text { Foaming agent }(\mathrm{F})\end{array}$}} & & & & & & & & & & & & \\
\hline & & \multicolumn{3}{|c|}{1.263} & & & & \multicolumn{3}{|c|}{0.459} & \multirow{2}{*}{\multicolumn{3}{|c|}{0.814}} \\
\hline \multicolumn{2}{|l|}{$\mathbf{P} \times \mathbf{F}$} & \multicolumn{3}{|c|}{ NS } & \multicolumn{3}{|c|}{$\begin{array}{l}0.516 \\
\text { NS }\end{array}$} & \multicolumn{3}{|c|}{0.649} & & & \\
\hline
\end{tabular}

Where, NP = Natural Pulp; SP = Sweetened Pulp; Conc $=$ concentration;CMC $=$ Carboxy-methyl-cellulose; GMS = Glycerol-mono-stearate; Control= Powder obtained from pulp without using foaming agents. 
Table.5 Effect of foaming agents on quality characteristics of foam mat dried papaya powder

\begin{tabular}{|c|c|c|c|c|c|c|c|c|c|c|c|c|c|}
\hline \multirow[t]{2}{*}{$\begin{array}{l}\text { Foaming } \\
\text { agents }\end{array}$} & \multirow[t]{2}{*}{$\begin{array}{l}\text { Conc. } \\
(\%)\end{array}$} & \multicolumn{3}{|c|}{ Total Sugars (\%) } & \multicolumn{3}{|c|}{$\begin{array}{l}\text { Total Carotenoids } \\
(\mu \mathrm{g} / \mathbf{1 0 0 g})\end{array}$} & \multicolumn{3}{|c|}{$\begin{array}{c}\text { Titratable } \\
\text { acidity }(\%)\end{array}$} & \multicolumn{3}{|c|}{ pH } \\
\hline & & NP & SP & Mean & NP & SP & Mean & NP & $\mathbf{S P}$ & Mean & NP & SP & Mean \\
\hline \multirow{4}{*}{ CMC } & Control & 74.3 & 86.0 & 80.1 & 1341.2 & 1043.4 & 1192.3 & 0.28 & 0.15 & 0.21 & 5.1 & 5.3 & 5.2 \\
\hline & 1.0 & 76.7 & 86.4 & 81.4 & 1289.3 & 1005.4 & 1147.3 & 0.27 & 0.15 & 0.21 & 5.1 & 5.4 & 5.2 \\
\hline & 2.0 & 79.7 & 86.7 & 83.2 & 1271.3 & 992.0 & 1131.6 & 0.26 & 0.14 & 0.20 & 5.2 & 5.4 & 5.3 \\
\hline & 3.0 & 81.6 & 86.8 & 84.2 & 1256.4 & 973.0 & 1114.7 & 0.26 & 0.14 & 0.20 & 5.2 & 5.4 & 5.3 \\
\hline \multirow{3}{*}{ GMS } & 1.0 & 76.8 & 86.6 & 81.7 & 1243.4 & 970.9 & 1107.1 & 0.27 & 0.14 & 0.21 & 5.1 & 5.5 & 5.3 \\
\hline & 2.0 & 79.2 & 87.5 & 83.3 & 1283.1 & 960.1 & 1121.6 & 0.27 & 0.14 & 0.21 & 5.1 & 5.6 & 5.3 \\
\hline & 3.0 & 81.4 & 87.7 & 84.6 & 1243.0 & 928.8 & 1085.9 & 0.27 & 0.14 & 0.20 & 5.2 & 5.6 & 5.4 \\
\hline \multicolumn{2}{|l|}{ Mean } & & 79.2 & 86.9 & & & 971.7 & & 0.27 & 0.14 & & 5.1 & 5.5 \\
\hline \multirow{2}{*}{\multicolumn{2}{|c|}{$\begin{array}{l}C_{0.05} \\
\text { Pulp }(P) \\
\text { Foaming agent }(F) \\
P \times F\end{array}$}} & & \multirow{2}{*}{\multicolumn{2}{|c|}{$\begin{array}{l}0.429 \\
0.743 \\
1.051\end{array}$}} & \multirow{2}{*}{\multicolumn{3}{|c|}{$\begin{array}{c}8.790 \\
15.225 \\
21.532\end{array}$}} & \multirow{2}{*}{\multicolumn{3}{|c|}{$\begin{array}{c}0.002 \\
0.004 \\
\mathrm{NS}\end{array}$}} & \multirow{2}{*}{\multicolumn{3}{|c|}{$\begin{array}{c}0.149 \\
\mathrm{NS}\end{array}$}} \\
\hline & & & & & & & & & & & & & \\
\hline
\end{tabular}

Where, NP = Natural Pulp; SP = Sweetened Pulp; Conc.= concentration;CMC = Carboxy-methyl-cellulose; GMS = Glycerol-mono-stearate; Control= Powder obtained from pulp without using foaming agents.

Figure.1 Process for preparation of papaya fruit powder

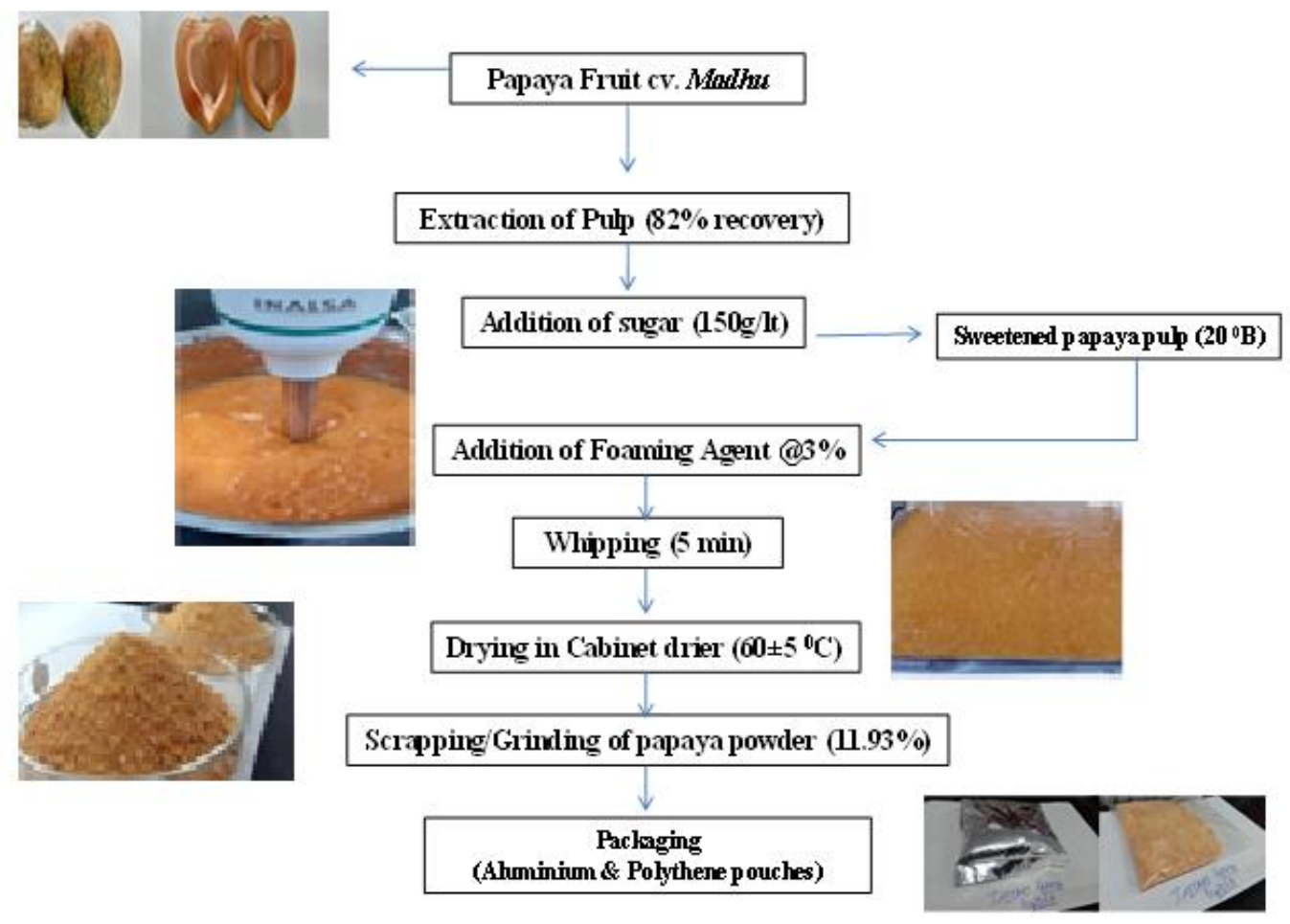


Figure.2 Effect of foaming agents on foam mat drying of papaya pulp cv. Madhu

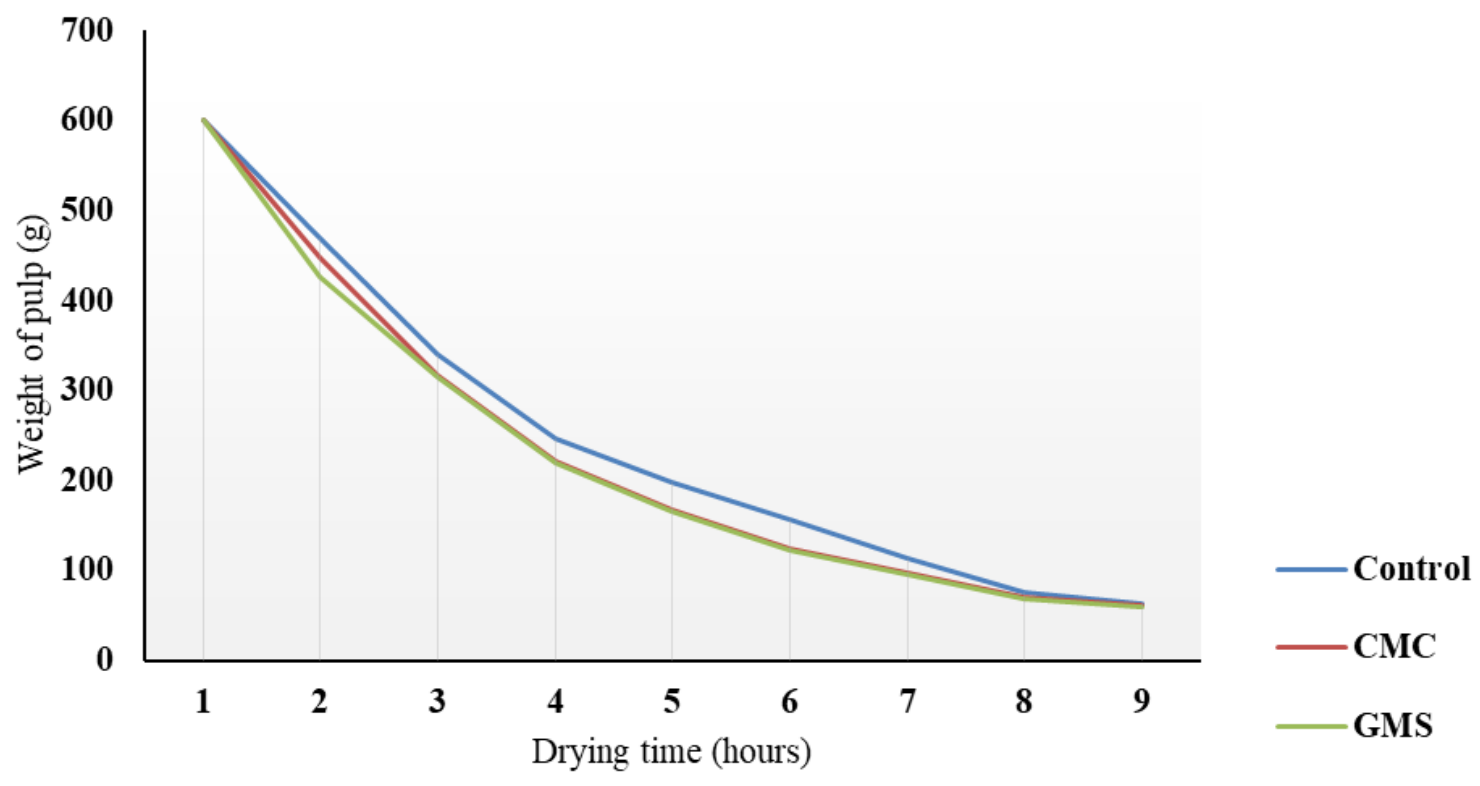

Figure.3 Sensory evaluation of papaya fruit powder (cv. Madhu) prepared by using different concentrations of foaming agents

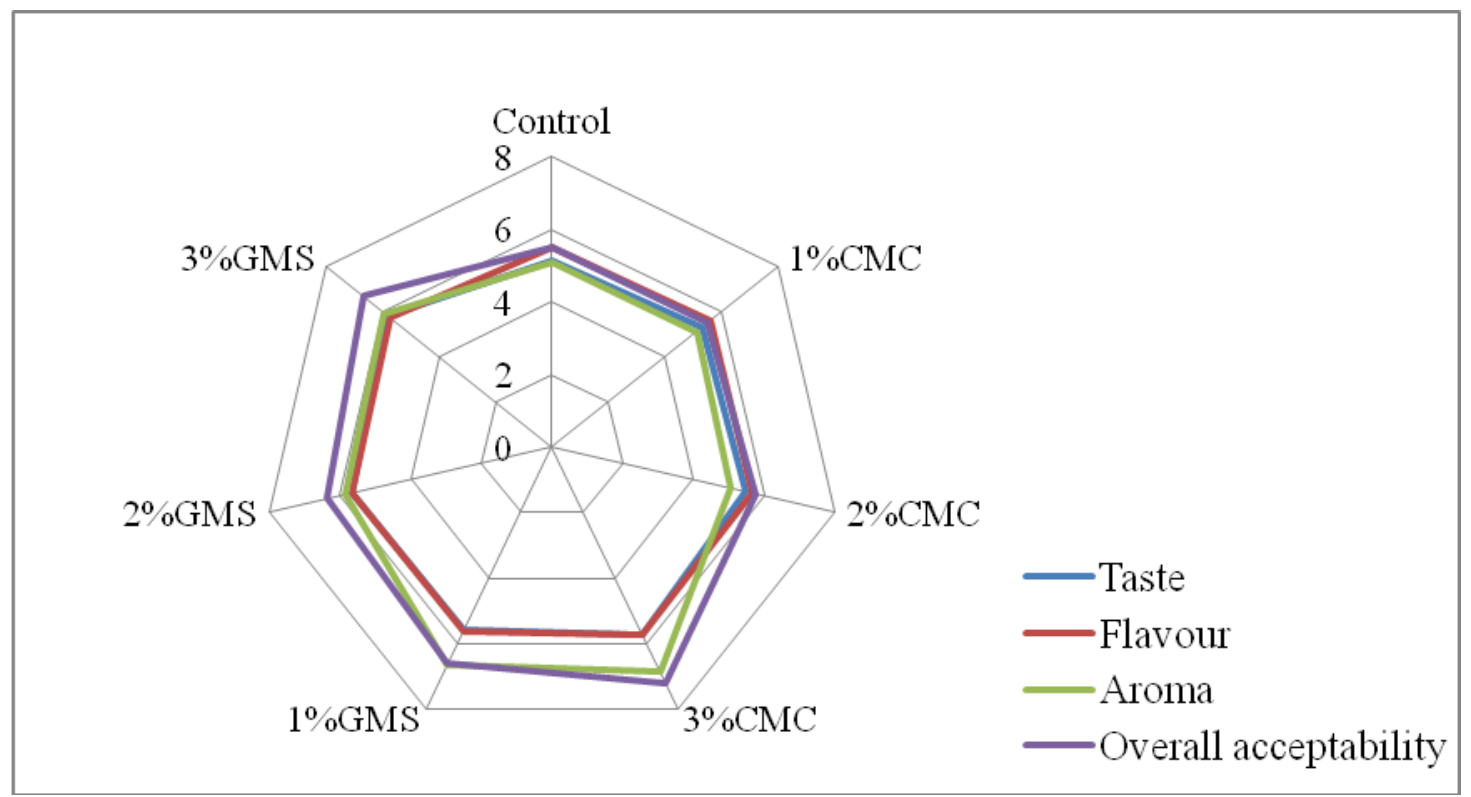

\section{Total sugars}

Table 5 indicated that the papaya powder prepared from sweetened pulp exhibited significantly higher 86.9 per cent total sugars as compared to natural pulp (79.2 per cent).
Among different foaming agents, the non foamed pulp had 80.1 per cent total sugars which increased to 81.4 to 84.2 per cent in powder prepared by using CMC (1-3\%) and 81.7 to 84.6 per cent in GMS (1-3\%) treated foamed papaya pulp powder.Increase in sugar 
content of foam-mat dried tomato with increasing the concentration of foam agents has been reported by Kadam et al., (2012a) which may be due to the inherent content of foaming agents used.

\section{Total carotenoid}

The data presented in Table 5shows that the papaya powder prepared from unsweetened natural pulp exhibited significantly higher (1264.3 $\mu \mathrm{g} / 100 \mathrm{~g})$ total carotenoids as compared to powder from sweetened pulp (971.7 $\mu \mathrm{g} / 100 \mathrm{~g})$. Among different foaming agents, the powder from un-foamed pulp had total carotenoids as $1192.3 \mu \mathrm{g} / 100 \mathrm{~g}$ which decreased from 1147.3 to $1114.7 \mu \mathrm{g} / 100 \mathrm{~g}$ in powder prepared by using CMC (1-3\%) and 1107.1 to $1085.9 \mu \mathrm{g} / 100 \mathrm{~g}$ in GMS $(1-3 \%)$ treated foamed papaya pulp powder. Similar trend of decline in total carotenoids was observed by Khamjae and Rojanakorn (2018) in passion fruit $(83.87-72.51 \mathrm{mg} / 100 \mathrm{~g})$ and Wilson et al., (2012) in mango powder. The loss of total carotene could be attributed to its photosensitive nature, isomerisation and epoxide forming nature of carotenoids (Mir and Nath, 1993).

\section{Titratable acidity}

The papaya powder prepared from natural pulp exhibited significantly higher titratable acidity (0.27 per cent) as compared to sweetened pulp (0.14 per cent). Among different foaming agents, the powder from unfoamed pulp had 0.21 per cent titratable acidity (Table 5). With increase in the concentration of foaming agents non significant effect was observed. The powder prepared by using 1\% GMS resulted in a titratable acidity of 0.27 per cent. Similar trends in titratable acidity has been reported by Sharma et al., (2002) in hill lemon juice powder, Shaari et al., (2017) in pineapple powders, Gupta and Alam (2014) in foam mat dried grape bar and Kadam et al., (2011) in mandarin powder.

\section{pH}

Among different foaming agents, the powder from un-foamed pulp had $\mathrm{pH}$ value of 5.2. With increase in the concentration of foaming agents $(1-3 \%)$, the values of $\mathrm{pH}$ in dried papaya powder increased to 5.2-5.3 in powder prepared by using CMC and 5.3-5.4 in GMS (Table 5). Among different concentration of foaming agents, it was found that with the increase in concentration of the foaming agents, the $\mathrm{pH}$ of the resultant powder exhibited increase. Gradual increase in $\mathrm{pH}$ (3.7-4.8) with increase in concentration of foaming agent has also been reported by Kadam et al., (2011) in mandarin powder and by Shaari et al., (2017) in foam mat dried pineapple fruit.

\section{Sensory evaluation}

Sensory evaluation of papaya fruit powder of natural and sweetened pulp prepared by using $1-3 \%$ concentrations of CMC and GMS is shown in Figure 3. The mean hedonic score for the powder prepared from sweetened pulp was significantly higher (6.32) in comparison to natural pulp. Further, among foaming agents, the powder obtained from papaya pulp foam by using GMS was superior in taste with a mean score (5.57-5.78) as compared to CMS. The powder prepared by using 3\% GMS in sweetened pulp was liked the most. The mean Hedonic score (9-point scale) for overall acceptability from the papaya powder prepared from sweetened pulp was significantly higher (7.33) in comparison to natural pulp. Among the foaming agents, the powder obtained from papaya pulp by using GMS was rated higher (6.35-6.65) as compared to $\mathrm{CMC}$. Therefore the papaya powder prepared from 3\% GMS obtained the highest sensory score on the basis of taste, 
flavour, aroma and overall acceptability indicating better acceptability (Figure 3 ).

It is concluded, on the basis of all physicochemical characteristics, effect of foaming agents on foaming characteristics of papaya pulp and sensory evaluation of papaya powder, the use of 3\% glycerol-mono-stearate (GMS) followed by foam mat drying of the resultant foam in dehydrator $\left(60 \pm 5^{\circ} \mathrm{C}\right)$ to a constant moisture content has been found the most appropriate and suitable for drying of papaya pulp. Thus, the technique can be used for commercial production of papaya powder for further utilization in development of ready-to-serve beverage by reconstituting the powder.

\section{References}

Affandi N, Zzaman W, Yang T A and Easa A M. 2017. Production of Nigella sativa beverage powder under foam mat drying using egg albumen as a foaming agent. Beverages 3(9): 1-15.

Ahuja J J, Montville G, Omolewa-Tomobi G, Heendeniya K and Ingwersen L. 2008. USDA food and nutrition database for dietary studies. Agricultural Research Service 3.0.

Akhtar S, Abid H, Yasmin A and Masood S. 2010. Preparation and evaluation of physical and chemical characteristics of instant mango juice powder. Pakistan Journal of Biochemistry and Molecular Biology 43(2): 58-60.

Akiokato A T, Matsudomi N and Kobayashi K. 1983.Determination of foaming properties of egg white by conductivity measurements. Journal of Food Science and Technology 48(1): 62-65.

Amerine M A, Pangborn R M and Rossler E B. 1965.Principles of sensory evaluation of food. Academic Press, New York. p: 254.

AOAC. 1995. Official methods of analysis of association of official analytical chemists, $16^{\text {th }}$ edition. Vol.I and II.Association of Official Analytical Chemists, Arlington, Virginia, USA.

Attri S, Dhiman A K, Kaushal M and Sharma R. 2014.Development and storage stability of Papaya (Caricapapaya L.) toffee and leather.International Journal of Farm Sciences 4(3): 117-125.

Auisakchaiyoung T and Rojanakorn T. 2015. Effect of foam-mat drying conditions on quality of dried $\mathrm{Gac}$ fruit (Momordicacochinchinensis) aril. International Journal of Food Research 22(5): 2025-2031.

Bag S K, Srivastav P P and Mishra H N. 2011.Optimization of process parameters for foaming of Bael (Aeglemarmelos L.) fruit pulp.Food Bioprocess Technology 4: 1450-1458.

Bari L, Hassan M P, Absar N, Haque M E and Khuda M I I E. 2006.Nutritional analysis of two varieties of papaya (Carica papaya) at different maturation stages. Pakistan Journal of Biological Science 9: 137-140.

Chauhan O P and Chatterjee T. 2005.A study on the development of papaya sauce. Beverage and Food World 32(1): 28-30.

Chukwuka K S, Iwuagwu M and Uka U N. 2013. Evaluation of nutritional components of Carica papaya L. at different stages of ripening. Journal of Pharmacy and Biological Sciences 6(4): 13-16.

Cochran W G and Cox C M. 1967. Experimental Designs. John Wiley and Sons, Inc. New York CRC Press, London, UK.

Devaki C S, Samreen F and Prakash J. 2015.A review on composition, processed products and medicinal uses of papaya (Carica papaya L).International Journal of Food, Nutrition and Dietetics 3(3): 99-117.

Falade F O, Adeyanju K I and Uzo-Peters P I. 
2003. Foam mat drying of cowpea (Vigna unguiculata) using glyceryl monostearate and egg albumen as foaming agents. Food Research Technology 217: 486-491.

Gajanana TM, Mysore S, Saxena A, Dakshinamoorthy V. 2010. Post harvest handling, marketing and assessment of losses in papaya. Actahorticulturae, 851:519-526.

Gopalan C, Ramasastri B V and Balasubramanium S C. 1989.Nutritive value of Indian foods. National Institute of Nutrition. ICMR Hyderabad, p161.

Gopalan C, Ramashastri B V, Balasubramanian S C, Rao N B S, Deosthale Y G and Pant K C. 2004. Nutritive value of Indian foods, National Institute of Nutrition. ICMR, Hyderabad (Revised).

Gupta K and Alam M S. 2014. Formulation and optimization of foam mat dried grape bar. International Journal of Agriculture Engineering 16(4): 228239.

Hassan M and Ahmed J. 1998. Sensory quality of foam-mat dried pineapple juice powder. Indian Food Packer 52(7): 31-33.

Jayaraman K S. 1993. Some process technologies for the preparation of convenience foods from fruits and vegetables for defence services. Indian Food Industry 12(5): 32-40.

Kadam D M and Balasubramanian S. 2011. Foam mat drying of tomato juice. Journal of Food Processing and Preservation 35(4): 488-495.

Kadam D M, Rai D R, Patil R T, Wilson R A, Kaur S and Kumar R. 2011. Quality of fresh and stored foam mat dried mandarin powder. International Journal of Food Science and Technology 46: 793-799.

Kadam D M, Wilson R A and Kaur S. 2010. Determination of biochemical properties of foam mat dried mango powder. International Journal of Food Science and Technology 45(8): 6261632.

Kadam D M, Wilson R A and Kaur S. 2012. Influence of foam-mat drying on quality of tomato powder. International Journal of Food Properties 10: 10801094.

Kandasamy P, Varadharaju N, Kalemullah S and Moitra R. 2012b. Preparation of papaya powder under foam-mat drying technique using egg albumin as foaming agent. International Journal of Bioresource and Stress Management 3(3): 324-331.

Khamjae T and Rojanakorn T. 2018.Foammat drying of passion fruit aril. International Journal of Food Research 25(1): 204-212.

Kudra T and Ratti C. 2006. Foam-mat drying: Energy and cost analysis. Canadian Biosystems Engineering 48: 327-332.

Mahony M O. 1985. Sensory evaluation of food: statistical methods and procedures. Marcel Dekker Inc., New York. 132p.

Marinova K G, Basheva E S, Nenova B, Temelska M, Mirarefi A Y, Campbell B and Ivanov I B. 2009. Physico-chemical factors controlling the formability and foam stability of milk proteins: Sodium caseinate and whey protein concentrates. Food Hydrocoll 37: 498506.

Meena A, Jawake P, Jain S K, Mudgal V D, Saloda M A and Sharma K C. 2014. Foam mat drying of papaya. Journal of Agricultural Engineering 51(3): 9-18.

Mir M A and Nath N. 1993. Storage changes in fortified mango bars. Journal of Food Science and Technology 30: 279-287.

NHB 2018. India Horticulture Database 2018. National Horticultural Board, Ministry of Agriculture, Co-operation and Farmers Welfare Government of 
India, Gurgaon p: 189-278.

Ojo O C, Theresa E, Adejoh O, Ekereke O R, David E and Maji A A. 2015. Foam-mat dehydration effect on the physical properties, micronutrient contents and sensory characteristics of pineapple and cashew apple juice powder. British Journal of Applied Science and Technology 7(2): 205-212.

Othman O C. 2009. Physical and chemical composition of storage ripened papaya (Carica papaya) fruits of Eastern Tanzania. Tanzania Journal of Sciences 35: 47-56.

Parker T L, Esgro S T, Samantha H, Miller A, Lauren E, Rustin A M, Stoyan A and Nicki J E. 2010. Development of an optimized papaya pulp nectar using a combination of irradiation and mild heat. Food Chemistry 118: 861-869.

Patil V, Chauhan A K and Singh S P. 2014. Influence of spray drying technology on the physical and nutritional properties of guava powder. International Journal of Current Microbiology and Applied Sciences 3(9): 1224-1237.

Rajarathnam S, 2010. Perspectives of processing papaya (Carica papaya) fruit: National and International strategies. International Society for Horticulture Sciences. Acta Horticulture $\quad 2^{\text {nd }} \quad$ International Symposium on papaya 851: 547-554.

Rajkumar $\mathrm{P}$ and Kailappan R. 2006.Optimizing the process parameters for foam mat drying of Totapuri mango pulp. Madras Agriculture Journal 93(16): 86-98.

Rajkumar P, Kailappan R, Viswanathan R and Raghavan G S V. 2007a.Drying characteristics of foamed alphonso mango pulp in a continuous type foam mat dryer. Journal of Food Engineering 79: 1452-1459.

Rajkumar P, Kailappan R, Viswanathan R, Parvathi $\mathrm{K}$ and Raghavan $\mathrm{G} \mathrm{S}$ V. 2007b. Thin layer drying study on foamed mango pulp. International Journal of Commission of Agriculture and Biosystem Engineering p: 224-238.

Ranganna S. 2014. Handbook of Analysis and Quality Control for Fruit and Vegetable Products. Tata McGraw Hills Publishing Co. Ltd., New Delhi. 11112.

Reni M, Sheela K B and Raju V K. 2000.Physico-chemical composition of different papaya varieties. Journal of Tropical Agriculture 38: 92-93

Sana N K, Karim M R, Sarkar B C, Sarkar G K and Shaha R K. 2009. Nutritional analysis and enzyme activities from the different stages of papaya flesh (Carica papaya L.). An Indian Journal of Biochemistry 3(2): 53-57.

Sankat C K and Castaigne F F. 2004. Foaming and drying of ripe bananas. Journal of Food Science and Technology 37(5): 517-525.

Santos L E O and Realpe D P L. 2013.Lycopene concentration and physico chemical properties of tropical fruits.Food and Nutrition Sciences 4: 758-762.

Shaari N A, Sulaiman R, Rahman R A and Bakar J. 2017. Production of pineapple fruit (Ananas comosus) powder using foam mat drying: effect of whipping time and egg albumen concentration. Journal of Food Processing and Preservation p: 1-10.

Sharma P C, Sharma S K and Kaushal B B. 2002. Studies on the preparation of foam mat dried hill lemon (Citrus pseudolimon Tan.) juice powder. Indian Food Packer 56(4): 67-71.

Sharma S K, Sharma P C and Kaushal B B L. 2004. Storage studies of foam mat dried hill lemon (Citrus pseudolimon Tan.) juice powder. Journal of Food Science and Technology 41(1): 9-13.

Sidhu J S. 2006. Tropical fruits. Handbook of 
Fruits and Fruit Processing. Second edition, Wiley-Blackwell publishing, USA p: 597-634.

Thuwapanichayanan R, Prachayawarakorn S and Soponronnarit S. 2008.Drying characteristics and quality of banana foam mat. Journal of Food Engineering 86(4): 573-583.

Vij T and Prashar Y. 2015.A review on medicinal properties of Carica papaya Linn. Asian Pacific Journal of Tropical Disease 5(1): 1-6.

Widyastuti T E W, Marsono Y and Noor Z. 2003. Characterization of papaya flour as laxative agent: intestinal response of
SpaqueDawley rats. Processing of National Seminar of Indonesian Association of Food Technologists. Yogtakarta, Indonesia.

Wilson R A, Kadam D M, Chadha S and Sharma M. 2012. Foam mat drying characteristics of mango pulp. International Journal of Food Science and Nutrition Engineering 2(4): 63-69.

Zamen W, Biswas S K, Helali M O H, Ibrahim $M$ and Hassan P. 2006. Physico-chemical composition of four papaya varieties grown at Rajshahi. Journal of Biosciences 14: 83-86.

\section{How to cite this article:}

Shivani, Anil K. Verma, P.C. Sharma, Anil Gupta and Manisha Kaushal. 2019. Effect of Foaming Agent on Quality and Yield of Foam Mat Dried Papaya Powder. Int.J.Curr.Microbiol.App.Sci. 8(12): 2821-2835. doi: https://doi.org/10.20546/ijcmas.2019.812.330 